\title{
JANUSZ GRUCHAŁA
}

\author{
POLITYCY GALICYJSCY WOBEC SYTUACJI WEWNĘTRZNEJ \\ W AUSTRO-WĘGRZECH W KOŃCU PIERWSZEJ WOJNY ŚWIATOWEJ \\ (1917-1918)
}

Przyjęta przez konserwatystów zachodniogalicyjskich i demokratów bezprzymiotnikowych orientacja austro-polska, a także, chociaż nie bez zastrzeżeń, przez narodowych demokratów, ludowców, socjalistów i konserwatystów wschodniogalicyjskich, sprawiła, że sytuacja wewnętrzna w monarchii habsburskiej budziła zainteresowanie tych stronnictw. Rzutowała ona bowiem na położenie polityczno-militarne monarchii podczas wojny, zwłaszcza jej stosunki z Rzeszą Niemiecką, oraz stanowisko władz w Wiedniu wobec sprawy polskiej. Nie mogło przy tym pozostawać dla polityków galicyjskich tajemnicą, że zwycięskie dla państw centralnych zakończenie wojny przyniesie utrzymanie integralności terytorialnej krajów Korony św. Stefana i hegemonii madziarskiej w Zalitawii oraz wzmocnienia pozycji Niemców austriackich w Przedlitawii. Dawał temu dobitnie wyraz prezes naczelnego Komitetu Narodowego (NKN), przywódca konserwatystów zachodniogalicyjskich Władysław Leopold Jaworski, w opublikowanym na początku wojny artykule na łamach poczytnego czasopisma węgierskiego, „Az Est”: „Dążące do własnego bytu państwowego pod berłem dynastii Habsburskiej i w związku z monarchią austriacko-węgierską, że obecna wojna zakończona naszym zwycięstwem, przyniesie wzmocnienie wpływu państwa węgierskiego. Nie widzę nigdzie sprzeczności między uzasadnionymi aspiracjami Węgrów a swoim programem, jak liczę też na zrozumienie sytuacji przez Niemców austriackich"1.

Równocześnie zwolennicy orientacji austro-polskiej wskazywali na wspólne interesy narodowe Polaków i Węgrów, jakim było zagrożenie ze strony Rosji. Zgodnie z tym stanowiskiem podkreślano, że może ono zostać zlikwidowane poprzez utworzenie związanego z Austro-Węgrami państwa polskiego. Zwracał uwagę na ten fakt współpracujący z NKN-em późniejszy jego przedstawiciel w Budapeszcie, profesor Jan Dąbrowski w organie prasowym tej instytucji, „Wiadomościach Polskich”, w końcu 1915 r.: „Chwila, w której Rosja oparła swe granice o stoki Karpat, byłaby dla Węgier jednoznaczna z klęską mohacką (...) trwale i prawnie może odsunąć od granic Węgier

1 Cyt. za: „Wiadomości Polskie”, 6.03.1915, nr 19-20, s. 3. 
niebezpieczeństwo rosyjskie tylko państwo polskie (...) wskazuje interes własny Polakom potrzebę silnego państwa węgierskiego, które, idąc drogą swej naturalnej ekspansji na południe, nie może dopuścić, by na Bałkanie rozsiadły się wpływy polityczne rosyjskie, mając na celu opanowanie Konstantynopola, zamienić powoli tamtejsze państwa na rosyjskie gubernie, a w końcowym rezultacie podział Węgier jako końcowy efekt «oswoboditielnowo» programu Rosji wobec Słowian”2.

Powyższe enuncjacje zostały sformułowane również niewątpliwie pod wpływem silnych, zwłaszcza wśród arystokracji polskiej i węgierskiej, wzajemnych sympatii oraz oczekiwanej po wojnie rywalizacji z Niemcami austriackimi ${ }^{3}$. Z kolei po stronie węgierskiej sympatie propolskie ujawniły się nie tylko wśród opinii publicznej, lecz także wśród elit politycznych. Swoje stanowisko w kwestii polskiej przedstawiły one na przełomie września i października 1915 r. po zajęciu przez armie państw centralnych Królestwa Polskiego podczas posiedzenia rządu z udziałem przywódców opozycji parlamentarnej. Premier István Tisza, który na początku wojny dał się poznać jako jeden z głównych oponentów utworzenia związanego z monarchią habsburską państwa polskiego z obawy, że realizacja tej koncepcji zagrozi dualistycznej strukturze ustrojowo-politycznej monarchii i osłabi w niej pozycję Węgrów ${ }^{4}$, sprzeciwiał się wówczas przekształceniu Austro-Węgier w państwo trialistyczne. Mogło to zaś nastąpić w wypadku przyłączenia do monarchii części zaboru rosyjskiego. Za rozwiązaniem trialistycznym opowiadał się natomiast stanowczo jeden z przywódców opozycji, syn byłego premiera węgierskiego i ministra spraw zagranicznych Austro-Węgier, Guyla Andrassy młodszy ${ }^{5}$. Identyczne poglądy proponował również Andrassy w drugiej połowie 1915 i pierwszej połowie 1916 r. na łamach prasy niemiecko-austriackiej i wydawanej w II Rzeszy. Ale realizację koncepcji austro-polskiej uzależniał on od zacieśnienia sojuszu politycznego i militarnego oraz współpracy gospodarczej między Niemcami a Austro-Węgrami. Polityk węgierski przy okazji niejako w imieniu zwolenników orientacji austro-polskiej wykluczał możliwość przyłączenia do państwa polskiego ziem zaboru pruskiego ${ }^{6}$.

Tymczasem latem 1916 r. nastąpiło dalsze osłabienie pozycji monarchii habsburskiej wobec sojusznika niemieckiego. Zaważyło to negatywnie na losach koncepcji austro-polskiej. W czasie rozmów przeprowadzonych przez austro-węgierskiego ministra spraw zagranicznych Istvána Buriána 11-12 sierpnia 1916 r. z kanclerzem Theobaldem von Bethmann-Hollwegiem ustalono bowiem, że z terytorium Królestwa Polskiego

2 J. Dąbrowski, Podstawy polityczne stosunku Polski do Wegier, „Wiadomości Polskie”, 25.12.1915, nr 57-58, s. 49-50.

3 J. Chlebowczyk, Między dyktatem, realiami a prawem do samostanowienia, Warszawa 1988, s. 238-239.

4 Tamże, s. 237-238; H. Batowski, Rozpad Austro-Wegier 1914-1918, Kraków 1982, s. 279-282; L. Grosfeld, Polityka państw centralnych wobec sprawy polskiej w latach 1914-1918, Warszawa 1962, s. 19.

${ }^{5}$ E. Luknich, Stanowisko rządu węierskiego wobec kwestii polskiej w pierwszych latach wojny światowej, „Kwartalnik Historyczny” 1938, z. 4, s. 630-633.

${ }^{6}$ L. Grosfeld, dz. cyt., s. 66-67. 
zostanie utworzone państwo polskie związane z państwami centralnymi, co oznaczało de facto jego uzależnienie od II Rzeszy. Decyzja ta została podjęta dopiero wtedy, kiedy nadzieje na zawarcie separatystycznego pokoju z Rosją okazały się nierealne. Władze w Berlinie nie zamierzały bowiem zwracać sąsiadowi wschodniemu zdobytych ziem polskich. Odrzucono również możliwość przyłączenia Królestwa Polskiego do Austro-Węgier, ponieważ nie chciano ich wzmocnienia i obawiano się zwiększenia liczebności ludności słowiańskiej w monarchii, co mogło zagrozić dominacji niemieckiej w Przedlitawii. Lekceważący stosunek kierownictwa politycznego II Rzeszy do sojusznika austro-węgierskiego ilustruje zamysł Bethmanna-Hollwego w sprawie zawarcia odrębnego pokoju z Rosją za cenę przekazania jej Galicji Wschodniej

W takiej sytuacji wydany zgodnie ze wspomnianym porozumieniem w Berlinie akt z 5 listopada 1916 r. przekreślił - chociaż niedefinitywnie - szanse na realizacje rozwiązania austro-polskiego. Akt ten oznaczał zarazem przynależność Galicji do monarchii habsburskiej. Dzień wcześniej ogłoszone zostało bowiem odręczne pismo cesarza Franciszka Józefa, które zapowiadało rozszerzenie autonomii Galicji. Miało ono na celu $\mathrm{z}$ jednej strony wykazać, że monarchia habsburska nie zamierza rezygnować $\mathrm{z}$ tej prowincji $\mathrm{w}$ wypadku utworzenia $\mathrm{z}$ części zaboru rosyjskiego, uzależnionego od Niemiec państwa polskiego oraz wychodziło naprzeciw aspiracjom stronnictw niemieckich, zmierzających do uzyskania większości w parlamencie wiedeńskim. Oprócz tego przedstawiało ono Polakom perspektywę jeszcze bardziej korzystnego niż dotychczas położenia $\mathrm{w}$ monarchii $\mathrm{w}$ celu przeciwstawienia się ewentualnym dążeniom irredentystycznym $\mathrm{z}$ ich strony ${ }^{8}$.

Równocześnie pismo cesarskie wywołało nadzieję wśród polityków czeskich, że rozszerzenie autonomii stworzy możliwość do przeprowadzenia w Przedlitawii zmian ustrojowych w kierunku federalizmu. Nie odrzucali oni bowiem w tym czasie jeszcze możliwości realizacji czeskich aspiracji narodowych w ramach monarchii habsburskiej$^{9}$. Federalizacja Przedlitawii odsuwała zarazem perspektywę uzyskania przez stronnictwa niemieckie większości w Radzie Państwa. Nieprzypadkowo też zapowiedź wyodrębnienia Galicji zaniepokoiła niemieckie koła dyplomatyczne. Kierujący wówczas ambasadą niemiecką w Wiedniu chargé daffaîres Friedrich von Stolberg w raporcie do Bethmanna-Hollwega stwierdzał na ten temat m.in.: „Zmienione stanowisko Galicji będzie oddziaływać naturalnie na Czechów (...) wystąpią oni z większym naciskiem ze starym żądaniem, aby spełnić ich szczególne prawa narodowe i stworzyć samodzielne Królestwo Czech. Już teraz można dostrzec symptomy w tym kierunku"10.

Nadzieje na wyodrębnienie Galicji okazały się jednak wkrótce nierealne. Następca zmarłego 21 listopada 1916 r., cesarz Karol I, i nowy austro-węgierski minister spraw

7 J. Pajewski, Odbudowa państwa polskiego 1914-1918, Warszawa 1985, s. 118.

${ }^{8}$ M. Paulová, Tajný výbor (Maffie) a spolupráce s Jihoslovany v letech 1916-1918, Praha 1968, s. $47-48$.

9 Tamże, s. 49-50.

${ }^{10}$ Raport F. von Stolberga do T. von Bethmann-Hollwega z 8.11.1916, Politisches Archiv des Auswärtigen Amts. Österreich, R. 8976, Bd XXIV (brak numeru karty). 
zagranicznych Ottokar von Czernin und Chudenitz, który starał się wywierać wpływ na sytuację wewnętrzną w Przedlitawii, w obliczu rewolucji lutowej w Rosji i dążeń do szybkiego zakończenia wojny opowiadali się bowiem za wprowadzeniem w życie wyodrębnienia drogą parlamentarną. Stanowisko to podzielał sprawujący od końca 1916 r. urząd prezydenta ministrów Heinrich Clam-Martinic, który uzależniał także tę kwestię od wyników przyszłej konferencji pokojowej ${ }^{11}$, jakkolwiek nie wykluczał jej rozwiązania wcześniej drogą parlamentarną ${ }^{12}$. Wiadomo zaś było, że w Radzie Państwa wymagana była w tym celu większość dwóch trzecich głosów. Trudno było jednak liczyć na uzyskanie takiej większości, ponieważ należało oczekiwać sprzeciwu posłów czeskich, południowosłowiańskich i ukraińskich, ale i części niemieckich. Ci ostatni byli związani z wielkim przemysłem i nie byli skłonni zaakceptować szerokiej autonomii władz krajowych oraz postulatów ekonomicznych w celu przyśpieszenia rozwoju przemysłu w Galicji, z którymi występowali politycy polscy ${ }^{13}$.

Kluczowe znaczenie przedstawiało jednak stanowisko cesarza wobec sprawy wyodrębnienia, które doprowadziło w końcu kwietnia 1917 r. do dymisji ministra dla spraw Galicji Michała Bobrzyńskiego ${ }^{14}$.

Przekreślenie możliwości wyodrębnienia Galicji drogą oktrojowaną wywołało wśród polityków czeskich nadzieje, próba wprowadzenia w życie zapowiedzi pisma cesarskiego w parlamencie wiedeńskim stworzy sprzyjające warunki do przeprowadzenia zmian ustrojowych w Przedlitawii w kierunku federalizmu. Dawał temu wyraz organ prasowy czeskiego stronnictwa prawicowego, Narodowej Partii Wolnomyślnej, „Národní listy”, którego komentarze - jak można sądzić - odzwierciedlały stanowisko utworzonego w końcu listopada 1916 r. Związku Czeskiego, grupującego posłów czeskich do Rady Państwa. Nawiązując do dymisji Bobrzyńskiego, konstatowano tam m.in.: „Posłowie czescy będą postępować $\mathrm{w}$ duchu programu polskiego, w duchu autonomizmu polskiego, domagającego się, aby razem $\mathrm{z}$ rozszerzeniem autonomii galicyjskiej został uregulowany stosunek ich krajów do całości państwa według narodowej, głośno uznawanej zasady sprawiedliwości i samostanowienia narodów. Również ich dążenia nie będą nigdy kierować się na osłabienie całości państwa, lecz na zwiększenie wszelkich jego sił i dlatego wierzymy, że nasza reprezentacja poselska znajdzie u Polaków takie samo zrozumienie, z jakim ich dążenia znajdują się u nas"15.

Tymczasem znane orędzie prezydenta Stanów Zjednoczonych Thomasa Woodrow Wilsona z 22 stycznia 1917 r. do Kongresu, w którym zostało wymienione utworzenie niepodległego państwa polskiego jako jeden z warunków przyszłego pokoju, rewolucja lutowa w Rosji oraz decyzja kierownictwa politycznego Austro-Węgier o zwołaniu Rady Państwa przyniosły wzrost aspiracji niepodległościowych społeczeństwa polskiego

${ }^{11}$ F. Höglinger, Ministerpräsident Heinrich Graf Clam-Martinic, Graz-Köln 1964, s. 153.

12 W. Łazuga, Michał Bobrzyński. Myśl historyczna a działalność polityczna, Warszawa 1982, s. 196.

${ }^{13}$ H. Lemke, Allianz und Rivalität. Die Mittelmächte und Polen im ersted Weltkrieg (bis zur Februarrevolution), Berlin 1977, s. 430.

14 W. Lazuga, dz. cyt., s. 198-199.

15 „Národní listy”, 2.05.1917, nr 119, s. 1. 
w Galicji. Wyraziła je uchwalona 16 maja 1917 r. przez Koło Polskie w Wiedniu, a następnie potwierdzona przez posłów do Sejmu Krajowego i Rady Państwa 28 maja w Krakowie, rezolucja. Zawierała ona postulat utworzenia niepodległego państwa polskiego z dostępem do morza. Rezolucja ta miała charakter antyniemiecki, ponieważ w dosłownej interpretacji domagała się przyłączenia do państwa polskiego także zaboru pruskiego. Świadczyła ona zarazem, że większość posłów polskich, zwłaszcza narodowi demokraci i ludowcy, zaakceptowała orientację prokoalicyjną. Nie oznaczało to jednak zerwania $\mathrm{z}$ orientacją austro-polską, ponieważ w rezolucji wyrażano nadzieję, że Austro-Węgry udzielą poparcia polskim aspiracjom niepodległościowym. Niemniej uchwały majowe postawiły władze w Wiedniu w kłopotliwej sytuacji wobec sojusznika niemieckiego. Nieprzypadkowo też Czenin i Clam-Martin w rozmowach z przywódcami Koła Polskiego w Wiedniu wskazywali na niezadowolenie władz w Berlinie z powodu rezolucji i domagali się złagodzenia jej antyniemieckiej treści ${ }^{16}$. Równocześnie zgodne z tym stanowiskiem Ministerstwo Spraw Wewnętrznych żądało od namiestnika Galicji, generała Karla Huyna, aby „z wszelką stanowczością przeciwstawił się żywiołom sprzecznym z naszymi interesami państwowymi” ${ }^{\prime 7}$.

Uchwały majowe wywołały również wśród polityków czeskich nadzieję na zmianę dotychczasowej, prorządowej polityki Koła Polskiego i nawiązanie przez nie w parlamencie wiedeńskim współpracy ze stronnictwami słowiańskimi. „Národní listy”, komentując rezolucję posłów galicyjskich z 28 maja, pisały bowiem m.in.: „Ich niedzielne, krakowskie uczynki są ogromne, ale wyrażona tam ich solidarność jest zachwycająca, aby właściwie oddziaływały na wszystkich (...) Rada Państwa (...) będzie światkiem, że dotychczasowy, austriacki system wewnętrzny jest od dziś (...) niemożliwy, jak w rzeczywistości był niemożliwy i nie do utrzymania już od dawna"18.

Tymczasem otwarcie 30 maja 1917 r. zawieszonej po wybuchu wojny Rady Państwa dostarczyło okazji do prezentacji aspiracji narodowych przez posłów słowiańskich. Najpierw w tym samym dniu przywódca Słoweńskiej Partii Ludowej Anton Korošec złożył w imieniu utworzonego Klubu Jugosłowiańskiego, grupującego posłów słoweńskich i chorwackich z Dalmacji i Istrii, deklarację, w której domagał się zjednoczenia wszystkich ziem południowosłowiańskich w monarchii habsburskiej „pod berłem dynastii habsbursko-lotaryńskiej”. Z kolei prezes Związku Czeskiego František Staněk przedstawił dalej idącą deklarację, żądającą przekształcenia monarchii w federację wolnych i równouprawnionych narodów, w skład której miało wchodzić państwo czeskie, obejmujące kraje czeskie w granicach historycznych i ziemie słowackie ${ }^{19}$. Natomiast przedstawiciele Koła Polskiego łącznie z jego prezesem Stanisławem Łazarskim przedstawili w swoich wystąpieniach polskie dążenia niepodległościowe zgodnie $\mathrm{z}$ uchwałami majowymi ${ }^{20}$.

16 J. Pajewski, dz. cyt., s. 195-196.

17 Pismo Ministerstwa Spraw Wewnętrznych do namiestnika Galicji z 30.05.1917, Allgemeines Verwaltungsarchiv. Ministerium des Intern, Fasz. 2117 (brak numeru karty).

18 „Národní listy”, 30.05.1917, nr 146, s. 1.

19 J. Chlebowczyk, dz. cyt., s. 347; H. Batowski, dz. cyt., s. 153.

${ }^{20}$ J. Buszko, Polacy w parlamencie wiedeńskim 1848-1918, Warszawa 1996, s. 323-325. 
Posłowie galicyjscy nie odnieśli się jednak do deklaracji posłów czeskich i południowosłowiańskich, ponieważ realizacja zawartych w nich postulatów mogła nastąpić tylko w wyniku zmiany struktury ustrojowo-politycznej Austro-Węgier. Wszelkie zaś spekulacje na ten temat w sytuacji, kiedy postępował proces uzależnienia się monarchii habsburskiej od II Rzeszy, której kierownictwo polityczne i wojskowe było zainteresowane utrzymaniem dualizmu austriacko-węgierskiego, mogły być wyłącznie przedmiotem rozważań teoretycznych. $Z$ drugiej strony politycy galicyjscy mimo wyrażanych dążeń niepodległościowych nie porzucili koncepcji austro-polskiej, której realizacja była w dużym stopniu uzależniona od postawy polityków niemiecko-austriackich i węgierskich. Przemawiał za tym również fakt, iż kierownictwo polityczne Austro-Węgier i ambasador niemiecki w Wiedniu Botho von Wedel opowiadał się $\mathrm{w}$ tym czasie za rozwiązaniem austro-polskim ${ }^{21}$. W takiej sytuacji wszelkie enuncjacje na temat czeskich i południowosłowiańskich aspiracji narodowych mogły zniechęcić władze w Wiedniu oraz polityków niemiecko-austriackich i węgierskich do koncepcji austro-polskiej.

Z tego samego powodu na łamach prasy związanej ze stronnictwami polskimi, reprezentowanymi w Radzie Państwa, nie zamieszczono zbyt wiele komentarzy poświęconych deklaracji posłów czeskich i południowosłowiańskich. I tak, publicysta Konstanty Srokowski w organie demokratów, „Nowej Reformia”, dość wstrzemięźliwie odnosił się do przedstawionych w nich postulatów politycznych. Trafnie podkreślał, że nie wywrą one większego wpływu na sytuację polityczną w Przedlitawii, pisząc na ten temat m.in: „Czesi mogli od razu zacząć z tak wysokiego tonu. Uprawnia ich do tego ich położenie, w którym mają niewiele do stracenia poza tym, co już stracili, a bardzo wiele do uzyskania. Od wschodu nie grozi im żadne niebezpieczeństwo. $\mathrm{Z}$ innych stron przyjdzie im do pomocy czynnik tak silny jak racja stanu dynastii Habsburskiej. W obozie koalicji nie ma nikogo, kto by miał jawny lub ukryty interes przeciw zniszczeniu najświętszych pragnień narodu czeskiego (...) Jakkolwiek więc realna wartość proklamowanego onegdaj programu czeskiego zależy, jak wartość wszystkich w ogóle programów, od ostatniego wyniku wojny, to jednak nie można powiedzieć, aby Czesi popełnili błąd, proklamując ten program już teraz. W wojnie tej nic nie zyskali, nic więc nie ryzykują (...) W przeciwieństwie do kwestii czeskiej kwestia południowosłowiańska zahacza tylko jednym końcem o to forum, które stanowi parlament austriacki (...) Jądro kwestii południowosłowiańskiej leży po tamtej stronie Litwy. Tam też z pewnością onegdajsza ważna deklaracja południowosłowiańska znajdzie echo najsilniejsze"22.

Odcinali się natomiast jednoznacznie od czeskich aspiracji narodowych konserwatyści zachodniogalicyjscy, którzy uznawali je za niemożliwe do realizacji nawet po zakończeniu wojny. Takie stanowisko wynikało z przekonania, że Austro-Węgry zachowają byt państwowy bez względu na wyniki wojny. Organ stańczyków „Czas”,

${ }^{21}$ J. Gruchała, Polityka Austro-Wegier wobec sprawy polskiej i ukraińskiej w opinii dyplomacji niemieckiej 1917-1918, „Dzieje Najnowsze” 2008, nr 4, s. 64-65.

22 (k. s.), Otwarcie parlamentu, „Nowa Reforma”, 1.06.1917, nr 250, s. 1. 
nawiązując latem 1917 r. do absencji posłów czeskich w powołanej przez Radę Państwa komisji konstytucyjnej, tak pisał pod ich adresem: „żaden kongres (pokojowy - J. G.) o wewnętrznych sprawach austriackich rozstrzygać nie będzie, ale tego nie wiedzą Czesi; stoją przed hipnozą tego przypuszczenia i dlatego nie okazują się dostępnymi dla realnej rozwagi. Skoro wojna minie, skoro Czesi przekonają się, że i nadal, jak dotąd nie ma dla nich innej drogi oprócz kompromisu; nadejdzie dopiero czas do wspólnej z nimi pracy nad zmianą konstytucji”23. Z kolei J. Dąbrowski zgodnie z przesłanką, że politycy węgierscy są naturalnymi sojusznikami Polaków dla realizacji koncepcji austro-polskiej, polemizował w „Wiadomościach Polskich” z postulatem w sprawie przyłączenia Słowacji do państwa czeskiego, stwierdzając m.in. że: „politykom czeskim nie przyszło nawet na myśl zapytać się Słowaków, czy do państwa czeskiego należeć pragną. Z przedmiotowego punktu widzenia sprawa słowacka pozostawioną musi być porozumieniu się Słowaków i Węgrów, jako głównych czynników faktycznie uprawnionych do zabierania w niej głosu, lecz politycy czescy nie zadają sobie bynajmniej trudu uzasadnienia swoich pretensji do Słowacczyzny”. W dalszej części swoich wywodów Dąbrowski podkreślał, że dążenia polityków czeskich do przyłączenia ziem słowackich wynikają z ich zainteresowania uzyskaniem przez państwo czeskie bezpośredniego połączenia terytorialnego z Rosją, ponieważ: „Rozwiązałoby zagadnienie, nad którym łamali sobie głowę politycy entente przez trzy lata wojny, znaleziono by wreszcie połączenie Czech z resztą Słowiańszczyzny pominięciem «niepewnej Polski». Przez piękne podtatrzańskie doliny wyciągnąć można byłoby rękę z Pragi przez Halicz do Kijowa i Moskwy"24.

Tymczasem opozycja posłów czeskich i południowosłowiańskich zmusiła w końcu czerwca 1917 r. gabinet Clam-Martinica do złożenia dymisji. Do opozycji dołączyło również Koło Polskie, mimo że prezydent ministrów w rozmowie z jego kierownictwem obiecywał przywrócenie administracji cywilnej w Galicji oraz odszkodowania dla ludności z powodu szkód wyrządzonych w czasie wojny przez wojsko ${ }^{25}$. Równocześnie prezydium Koła postawiło jako warunek poparcia dla rządu włączenie do niego przedstawicieli Czechów i Słowian południowych ${ }^{26}$. Politycy galicyjscy zdawali sobie bowiem sprawę z tego, że ze względu na nacjonalistyczne dążenia stronnictw niemieckich utworzenie większości polsko-niemieckiej w Radzie Państwa przyniosłoby dalszą eskalację konfliktów narodowościowych w Przedlitawii. „Czas”, komentując dymisję rządu Clam-Martinica, dowodził, że: „nienaturalny charakter miałaby większość polsko-niemiecka, stojąca do walki przeciw Czechom i Słowianom południowym (...) Tego hr. Clam nie zrozumiał i dlatego na marne poszły jego dobra wola i ogólne polityczne zdolności”27. Z drugiej zaś strony wysuwany przez polityków niemieckich postulat podziału poszczególnych prowincji, zwłaszcza Czech, zgodnie

23 „Czas", 2.08.1917, nr 354, s. 1.

${ }^{24}$ J. Dąbrowski, Zasada, której nadużywaja, „Wiadomości Polskie”, 5.08.1917, nr 139, s. 2.

25 J. Buszko, dz. cyt., s. 325.

${ }^{26}$ F. Höglinger, dz. cyt., s. 199.

27 „Czas”, 27.06.1917, nr 287, s. 1. 
ze stosunkami etnicznymi mógł sprzyjać aspiracjom ukraińskim, zmierzającym do podziału Galicji. Zwracał na to uwagę ten sam „Czas”: „podział kraju na okręgi może być przeprowadzony tak, ażeby przez najsztuczniejsze wykrawanie okręgów stworzyć reprezentacje okręgowe z pewną władzą ustawodawczą, a przez to zredukować znaczenie sejmu i obniżyć polityczne stanowisko krajów koronnych. Dla Niemców taka rewizja konstytucji może przedstawiać korzyści, bo może łączyć się z wielkim wzmocnieniem władz centralnych, zarówno administracyjnych jak ustawodawczych, lecz dla Polaków?"28

Obawy te były w pełni uzasadnione. Powołany w końcu czerwca 1917 r. urzędniczy gabinet Ernsta von Seidlera w celu przeciwstawienia się aspiracjom narodowym Czechów i Słowian południowych wystąpił bowiem z postulatem wprowadzenia bliżej nieokreślonej autonomii narodowej ${ }^{29}$. Powołanie w skład tego gabinetu tzw. ministrów rodaków miało przygotować grunt polityczny w tym kierunku. Jako przedstawiciel Ukraińców znalazł się w rządzie profesor Uniwersytetu Praskiego, Iwan Horbaczewśkyj. Politycy polscy przyjęli plany Seidlera jako krok prowadzący do przebudowy ustroju politycznego Przedlitawii w kierunku federalizmu opartego na zasadach etnicznych. Panujące wówczas wśród nich nastroje oddaje opinia W. L. Jaworskiego: „Półwiekowa praca idzie na marne. Stanowisko Polaków przepadło. Zajmą je Rusini i Słoweńcy"30.

Towarzyszył temu niepokój, że opozycja posłów czeskich i południowosłowiańskich oraz nacjonalistyczne postulaty stronnictw niemieckich, zrzeszonych w Austriacko-Niemieckim Związku Narodowym, doprowadzą do zwiększenia działalności Rady Państwa, co da rządowi możliwość wprowadzenia w życie autonomii narodowej. „Czas”, oceniając postawę posłów czeskich, stwierdzał m.in.: „Życzymy narodowi czeskiemu największej pomyślności politycznej, jednak nie sądzimy, aby wybrana do tego celu droga była dobrą. Czesi postawili program maksymalny i stawiają wszystko na jedną kartę. A że ten program nie ma w Izbie i poza Izba widoków powodzenia, więc i parlament nie ma dla nich wartości. Całe więc ich działanie skierowane jest dziś ku wywołaniu trudności wewnętrznych i chaosu". Podobnie dziennik ten odnosił się do dążeń polityków niemieckich, pisząc na ten temat m.in.: „Ostra opozycja Czechów wzbudziła na nowo wśród Niemców nadzieje. Wobec tak daleko sięgających (...) roszczeń czeskich sądzą Niemcy, że uda im się ten, to inny rząd pozyskać (...) i urządzić Austrię według recepty niemieckiej. Związek więc w pierwszym rzędzie jest zainteresowany w zerwaniu parlamentu" ${ }^{31}$.

Negatywny stosunek polityków galicyjskich do czeskich aspiracji narodowych zwiększał sprzeciw posłów czeskich wobec rozwiązania austro-polskiego. F. Staněk wraz z A. Korošcem podkreślali bowiem w Izbie Posłów jesienią 1917 r., że w wypadku

28 „Czas”, 3.08.1917, nr 356, s. 1.

${ }^{29}$ M. Paulová, dz. cyt., s. 341. Seidler przedstawił ten projekt w Radzie Państwa 21.09.1917 r.

${ }^{30}$ W. L. Jaworski, Dariusz z lat 1914-1921, cz. 2, Archiwum PAN w Warszawie, sygn. III-84, k. 592, zapiska z 26.06.1917.

31 „Czas”, 1.10.1917, nr 452, s. 1. 
rozwiązania sprawy polskiej przez Austro-Węgry Czesi i Słowianie południowi zostaną w Przedlitawii zmajoryzowani przez Niemców, a Ukraińcy zejdą do roli mniejszości narodowej w przyszłym państwie polskim ${ }^{32}$. „Nowa Reforma”, nawiązując do tych wystąpień, konstatowała: „W jaki praktyczny sposób utrzymanie lub utrudnienie parlamentu austriackiego ma pomóc Czechom lub południowym Słowianom do osiągnięcia ich celów narodowych, trudno odgadnąć. Zdaje się jednak, że tego pytania nie zadali sobie nawet politycy tych narodów. Działali oni w myśl szablonu przy każdej sposobności, a tym bardziej nad urządzeniem państwowym jednego z bezpaństwowych narodów (Polaków - J. G.) . $^{33}$. Równocześnie organ demokratów ponownie uznawał aspiracje czeskie za nierealne ze względu na postulat przyłączenia Słowacji do państwa czeskiego. „Przy całym uznaniu słusznych praw narodu czeskiego - czytamy tam - i dla jego niezłomnej woli, z jaką ich dochodzi, nie braliśmy i nie bierzemy deklaracji prawno-państwowej czeskiej dosłownie, szczególnie w tym jej ustępie, który odnosi się do rewindykacji węgierskiej Słowaczyzny na rzecz przyszłego państwa św. Wacława, a to z tego prostego powodu, że nie widzimy po stronie czeskiej siły, która by mogła życzenie do zrealizować (...) Węgry mogą być spokojni o to, że Polacy nigdy nie przyłożą ręki do zamachu na ich państwo już nie tylko z powodu sympatii, którą żywią dla narodu węgierskiego i jego przywódców, ale także i to przede wszystkim w myśl elementarnego wskazania każdej zdrowej polityki - niemieszania się do spraw nie swoich" ${ }^{34}$.

Tymczasem rokowania pokojowe w Brześciu Litewskim przyniosły dalszy wzrost czeskich aspiracji narodowych. Ujawniły się one w uchwalonej 6 stycznia $1918 \mathrm{r}$. deklaracji posłów czeskich w Radzie Państwa i sejmach krajowych Czech, Moraw i Śląska. Powtórzono w niej nie tylko wcześniejszą proklamację w Radzie Państwa z 30 maja 1917 r., żądającą utworzenia państwa czeskiego łącznie ze Słowacją w ramach monarchii habsburskiej, lecz także przedstawiono postulat prawa narodów do samostanowienia jako warunek wszelkich rokowań pokojowych oraz udziału w nich przedstawicieli Czechów i Słowaków. Z deklaracją posłów czeskich solidaryzowali się politycy południowosłowiańscy ${ }^{35}$.

Eskalacja aspiracji narodowych Czechów i Słowian południowych, które ewoluowały w kierunku niepodległości, unaoczniły politykom galicyjskim konieczność przeprowadzenia zmian ustrojowych w Przedlitawii. Taki pogląd wyrażali nawet austrofilsko nastawieni demokraci. Dawał temu wyraz K. Srokowski: ,jak racja stanu monarchii austriacko-węgierskiej da się pogodzić z zasadą samostanowienia narodów? (...) Czy chce (monarchia habsburska - J. G.) zostać zlepkiem historycznych terytoriów, czy też decyduje się związać związkiem wolnych i równouprawnionych narodów" ${ }^{36}$. Natomiast wśród polityków opowiadających się za orientacją prokoalicyjną pojawiły

32 „Nowa Reforma”, 10.11.1917, nr 520, s. 3.

33 „Nowa Reforma”, 14.11.1917, nr 526, s. 1.

34 „Nowa Reforma”, 23.11.1917, nr 524, s. 1.

${ }^{35}$ M. Paulová, dz. cyt., s. 377.

${ }^{36}$ (k. s.), Klęska czy zwycięstwo, „Nowa Reforma”, 31.01.1918, nr 51, s. 1. 
się na początku 1918 r. głosy, w których wskazywano na potrzebę współpracy narodów zamieszkujących Europę Środkową w celu przeciwstawienia się hegemonii niemieckiej. Organ ludowców, „Kurier Lwowski”, którego komentarze - jak można sądzić - odzwierciedlały stanowisko Związku Międzypartyjnego, tak pisał na ten temat: „Pomysł utworzenia niemieckiej Europy środkowej jest wygodną formą rozwiązania tej sprawy, ale dla Polski jest niebezpieczny. Niemieckiemu pomysłowi feudalnej, reakcyjnej Europy należy przeciwstawić wzniosłą misję dziejową narodów zamieszkujących między Bałtykiem a Adriatykiem. Mają one rozwiązać wszelkie zadanie zorganizowania wielkiego związku państw niezawisłych, pomagania ujarzmionym narodom i łączenia ich rozkawałkowanych narodów. Na to potrzeba jedności i wzajemnego zaufania tych narodów"37.

Dystansowali się zaś od tej współpracy najbardziej żarliwi zwolennicy koncepcji austro-polskiej, konserwatyści zachodniogalicyjscy. „Czas”, nawiązując do propagandowej przez przywódcę Morawskiej Partii Ludowej, Adolfa Stránskiego, współpracy posłów polskich i czeskich w Radzie Państwa, stwierdzał m.in.: „Należy pamiętać, że p. (an) Stránský i jego najbliżsi koledzy pchając Czechów na drogę antydynastycznej, antywęgierskiej i republikańskiej opozycji, ryzykują dla nich bardzo mało. Nieudanie się jego planów nie pociągnie dla Czechów nawet utraty dotychczasowego stanowiska w monarchii. My zaś, wchodząc na tą drogę - chyba tylko dlatego, aby Czesi nie czuli się najmniej odosobnieni - ryzykujemy z dynastią, zatarg z Węgrami i podniesienie sprawy ruskiej w Galicji (...) Radykałowie czescy, idący wyraźnie ku irredencie, dopóki jej (po osiągnięciu jakiegoś modus vivendi z państwem, oczywiście kosztem Polaków) nie będą za stosowne uważali zaniechać, pchają Polaków obecnie także do irredenty, choćby kosztem zaprzepaszczenia naszych realnych korzyści”38.

Tymczasem pokój zawarty 9 lutego 1918 r. w Brześciu Litewskim przez państwa centralne z Ukraińską Republiką Ludową przewidywał przekazanie jej Chełmszczyzny i części Podlasia. Ponadto zawierał on tajną klauzulę, która zakładała utworzenie z Galicji Wschodniej odrębnej prowincji ukraińskiej. Delegacja austro-węgierska zobowiązała się przy tym, że decyzję o podziale Galicji podejmie Rada Państwa.

Pokój brzeski wykazał zarazem dwulicową politykę Austro-Węgier w sprawie polskiej, a także ich dalsze uzależnienie się od sojusznika niemieckiego. Równocześnie zmniejszył on nadzieje na realizację rozwiązania austro-polskiego. Nic więc dziwnego, że pokój ten wywołał w Galicji akcje protestacyjne i spotkał się z krytyką wszystkich stronnictw polskich łącznie z konserwatystami zachodniogalicyjskimi. Przykładowo, W. L. Jaworski tak oceniał znaczenie tego pokoju: „Dla nas pokój z Ukrainą jest klęską i ciosem z powodu utraty Chełmszczyzny i narodowego upokorzenia. Ale zwiększy się zło przez irredentę (polską - J. G.), która powstanie w Galicji przez konflikt z Ukraińcami, przez upadek koncepcji austro-polskiej (...) Jest to jednak początek rozkładu Austrii. Polacy w opozycji - to uniemożliwienie parlamentu i delegacji. Polacy pójdą

37 „Kurier Lwowski”, 25.01.1918, nr 42, s. 1.

38 „Czas”, 5.02.1918, nr 58, s. 1. 
ręka w rękę z Czechami. Czernin przyłożył więc rękę do własne macierzy, jest sługą Niemiec, nie sługą Habsburgów"39.

Zgodnie z wyrażonymi przez Jaworskiego obawami Koło Polskie większością jednego głosu podjęło w końcu lutego decyzję o nawiązaniu współpracy z posłami czeskimi i południowosłowiańskimi, co oznaczało przejście posłów galicyjskich do opozycji. Decyzja ta spotkała się z krytyką konserwatystów zachodniogalicyjskich. „Czas” konstatował na ten temat m.in.: „Stałe przymierze z Czechami zmobilizuje bowiem przeciwnym te wszystkie czynniki, którym Czesi wypowiedzieli wojnę, a na których pomoc my musimy, zwłaszcza chwili obecnej, liczyć (...) jeśli będziemy musieli popierać - jako konieczne następstwo związania się z blokiem (słowiańskim - J. G.) - projekty czeskie co do Słowaczyzny lub przyjąć ich hasło utworzenia niezawisłego Królestwa Czech (...) Zostalibyśmy w tej chwili wciągnięci w bellum contra omnes, a że sprawa chełmska byłaby pierwszą takiej wojny ofiarą, jest rzeczą pewną (...) Jeśli jednak opozycja nasza wywołana traktatem brzeskim, ma na celu gwarancję integralności Królestwa i niepodzielności Galicji - a w razie uzyskania tego celu powinna ustać, to tym samym nie ma podstaw do łączenia się na stałe z Czechami”"40.

Na początku marca Koło zmieniło jednak swoje stanowisko pod wpływem audiencji jego przywódców u cesarza Karola I. Monarcha oświadczył wówczas, „iż życzliwa polityka zgasłego cesarza Franciszka Józefa I prowadzoną zostanie i nadal będzie kontynuowana”. Konserwatyści zachodniogalicyjscy przyjęli tę enuncjację jako zapowiedź anulowania niekorzystnych dla Galicji postanowień pokoju brzeskiego. „Czas”, komentując tę audiencję, stwierdzał: „W tej ciężkiej sytuacji znalazł, jak się wydaje, sam monarcha wyjście (...) zaręczając słowem monarszym o niezmiennej życzliwości dla kraju zgodnie $\mathrm{z}$ tradycją pozostawioną mu przez zmarłego poprzednika. W tym tkwi zaprzeczenie o zamierzonym podziale kraju, a zarazem umożliwienie dalszej akcji Koła o rewizję traktatu brzeskiego, dla której przy życzliwości monarchy, otwierają się widoki powodzenia" ${ }^{31}$. W rezultacie posłowie galicyjscy głosowali w Radzie Państwa za budżetem i kredytami wojennymi ${ }^{42}$. Taka postawa spotkała się ze sprzeciwem socjalistów i narodowych demokratów, którzy w odpowiedzi na zmianę decyzji Koła opuścili jego szeregi ${ }^{43}$.

Poparcie udzielone rządowi Seidlera nie przesłaniało jednak politykom galicyjskim jego orientacji narodowoniemieckiej, którą popierał Czernin. Nawet negatywnie nastawieni do czeskich aspiracji narodowych konserwatyści zachodniogalicyjscy krytycznie odnosili się do stanowiska władz w Wiedniu wobec Czechów. „Czas” w związku z przemówieniem Czernina w Radzie Państwa, w którym zarzucał on

39 W. L. Jaworski, Diariusz 1914-1918, wybór i oprac. M. Czajka, Warszawa 1997, s. 247, zapiska z 11.02.1918.

40 „Czas”, 7.03.1918, nr 109, s. 1.

41 „Czas", 8.03.1918, nr 111, s. 1.

${ }^{42}$ Tamże; „Nowa Reforma”, 16.03.1918, nr 144, s. 1. Zob. J. Buszko, dz. cyt., s. 329.

43 A. Wątor, Narodowa Demokracja w Galicji do 1918 roku, Szczecin 2002, s. 362-363; J. Holzer, Polska Partia Socjalistyczna w latach 1917-1919, Warszawa 1962, s. 145. 
politykom czeskim prowadzenie działalności antypaństwowej ${ }^{44}$, dowodził, że: „zyska może hr. Czernin poklask sfer centralistycznych i wszechniemieckich, ale na stosunki wewnętrzne w monarchii nie oddziała chyba w sposób uspakajający. Wzburzywszy w ten sposób Czechów do ostateczności, uniemożliwi sobie samemu dalszy stosunek z jednym z najliczniejszych, najpracowitszych, najzamożniejszych szczepów monarchii, ale także utrudni? porozumienie ze sobą tym wszystkim żywiołom, które, chociaż potępiają politykę niektórych czeskich przywódców, niemniej nie mają ochoty ani zamiaru powierzyć się wyłącznie fali germanizowania i centralizmu w Austrii”" ${ }^{35}$. Równocześnie organ stańczyków z niepokojem odnotował wzrost nastrojów nacjonalistycznych wśród Niemców austriackich, wskazując na ich zagrożenie dla monarchii habsburskiej. Pisał na ten temat m.in.: „Żywioły umiarkowane i rozważne zostały od nich od lat już kilkunastu zepchnięte na drugi plan, a ster dostał się do rąk odcieni szowinistycznych, do których inne starają się swój diapazon dostrajać. Zwłaszcza podczas wojny szowinizm odcieni skrajnych, coraz mniej mówiących o patriotyzmie austriackim, coraz głośniej podporządkowujących go patriotyzmowi niemieckiemu i coraz mniej tających, że słabość Austrii może mieć z punktu widzenia ich dążeń jeszcze dobre strony”. W dalszej części swoich wywodów „Czas” podkreślał, że: „Umiarkowane odcienie Polaków, Czechów i Niemców, połączone ze sobą chęcią utrzymania silnej Austrii i ideą wierności dla dynastii - oto są bowiem czynniki, za których jedynie uporządkowanie stosunków parlamentarnych, a tym samym stosunków całego państwa może być dokonanym" ${ }^{\prime 4}$. Analogicznie oceniała postawę polityków niemiecko-austriackich „Nowa Reforma”: „Często, zarówno wewnątrz monarchii, jak i poza jej granicami, mówi się o ciągłym wzrastaniu zależności monarchii od Rzeszy niemieckiej (...) Jest nią spotęgowane do najwyższego stopnia ciążenie Niemców austriackich w kierunku podporządkowania się interesowi i kierunkowi politycznemu Rzeszy" ${ }^{47}$.

Tymczasem rząd Seidlera, wychodząc naprzeciw postulatom stronnictw niemieckich, wydał na początku maja 1918 r. dekret o podziale Czech na część czeską i niemiecką, który miał zostać wprowadzony w życie 1 stycznia 1919 r. Decyzja ta wywołała wśród polityków polskich obawy, że stworzy ona precedens w kierunku podziału Galicjii ${ }^{48}$. Zgodnie z tym stanowiskiem Koło Polskie zapowiedziało na początku czerwca opozycje wobec tego rządu, wskazując, że jego „działalność uważa za szkodliwąa"

Natomiast wcześniej na przełomie maja i czerwca minister do spraw Galicji Juliusz Twardowski prowadził ze stronnictwami niemieckimi, Austriacko-Niemieckim Związkiem Narodowym i Zjednoczeniem Chrześcijańsko-Społecznym, rozmowy w sprawie utworzenia większości parlamentarnej. W czasie tych rozmów domagał się od polityków niemieckich m.in. poparcia dla rozwiązania austro-polskiego, anulowania

${ }^{44}$ M. Paulová, dz. cyt., s. 424.

45 "Czas", 4.04.1918, nr 158, s. 1.

46 "Czas", 24.04.1918, nr 188, s. 1.

47 "Nowa Reforma”, 19.04.1918, nr 178, s. 1.

${ }^{48}$ M. Paulová, dz. cyt., s. 502.

49 „Nowa Reforma”, 23.06.1918, nr 266, s. 1. 
postanowienia pokoju brzeskiego w odniesieniu do Chełmszczyzny i umiędzynarodowienie dolnego biegu Wisły, aby państwo polskie uzyskało dostęp do Morza Bałtyckiego. Oprócz tego żądał podjęcia przez polityków niemieckich pośrednictwa w pertraktacjach z Ukraińcami, aby ci wyrazili zgodę na przyłączenie całej Galicji do zaboru rosyjskiego, obiecując im w zamian szeroką autonomię w przyszłym państwie polskim. Z kolei politycy niemieccy domagali się od Koła Polskiego akceptacji zacieśnienia sojuszu Austro-Węgier z Niemcami, co nastąpiło w wyniku zawartego 12 maja 1918 r. przez obydwa państwa układu w Spa, oraz poparcia przeciw czeskim i słowiańskim aspiracjom narodowym.

Rokowania te nie przyniosły jednak rezultatu, ponieważ posłowie polscy żądali dymisji gabinetu Seidlera. Postulat ten spotkał się ze sprzeciwem polityków niemieckich, którzy byli zainteresowani utrzymaniem tego rządu ze względu na wydany przez niego dekret o podziale Czech. Nie zamierzali oni także popierać koncepcji austro-polskiej ${ }^{50}$. Posłów galicyjskich do współpracy ze stronnictwami niemieckimi zniechęciło zaś ich nacjonalistyczne stanowisko. Zwracano na to uwagę w sprawozdaniu NKN z początku lipca: „Dla Koła Polskiego jest przeto wskazanym proste i jasne: czekać, aż austriackie stronnictwa niemieckie przebudzą się ze swego prowincjalizmu i staną na gruncie państwowym. Wówczas porozumienie ich z Polakami (...) będzie łatwym" ${ }^{51}$.

Taka postawa stronnictw niemieckich znalazła wyraz w ich zainteresowaniu ścisłym sojuszem militarno-politycznym monarchii habsburskiej z II Rzeszą. Oprócz aspiracji narodów słowiańskich przyczyniły się do tego radykalne koncepcje społeczne i polityczne, które pojawiły się w szeregach Socjaldemokratycznej Partii Austrii pod wpływem rewolucji rosyjskich. Ścisły sojusz miał bowiem nie tylko zapewnić dominującą pozycję ludności niemieckiej w zachodniej części monarchii, lecz także utrzymać jej konserwatywny charakter. W takiej sytuacji obstawanie przez władze w Wiedniu przy rozwiązaniu austro-polskim traktowano jako dodatkową przeszkodę na drodze do zacieśnienia tego sojuszu ${ }^{52}$.

Po niepowodzeniu rokowań polsko-niemieckich Koło Polskie podjęło w połowie lipca uchwałę, w której domagało się dymisji rządu Seidlera ${ }^{53}$. Ale jego komisja parlamentarna odrzuciła wniosek posłów ludowych w sprawie nawiązania współpracy z posłami czeskimi i południowosłowiańskimi ${ }^{54}$. Niemniej kierownictwo Koła negatywnie odnosiło się do polityki rządu Seidlera wobec narodów słowiańskich. Dawała temu wyraz „Nowa Reforma”: „Nie będziemy bronić Czechów i Słowian południowych, którzy sami potrafią się obronić (...) Narzucił (Seidler - J. G.) Czechom obwody, które dotąd są w prawdzie na papierze, ale ich do reszty rozdrażniły, zapowiedział represje w południowej Słowiańszczyźnie, a jak perfidnie postępował

${ }^{50}$ J. Gruchała, dz. cyt., s. 75.

${ }^{51}$ Sprawozdanie z 10.07.1918, Archiwum Państwowe w Krakowie. Zespół NKN (dalej cyt.: APKr.), mkr. 100.268 (brak numeru karty).

${ }^{52}$ L. Grosfeld, dz. cyt., s. 293-294.

53 „Czas”, 11.07.1918, nr 245, s. 1.

54 „Czas”, 15.07.1918, nr 253, s. 1. 
wobec Polaków, przewyższając pod tym względem nawet hr. Czernina, wystarczy podkreślić sprawę podziału Galicji. Koalicja nie miałaby w Austrii nic do roboty, gdyby jej nie przygotował terenu dr. Seidler" 55 .

Jednak prezes zmniejszonego personalnie Koła Polskiego Tadeusz Tertil pominął w swoim wystąpieniu aspiracje narodowe Czechów i Słowian południowych, ponieważ skupił się na obronie niepodzielności Galicji, mówiąc m.in.: „podział kraju jest rzeczą wykluczoną, tak samo wobec zapewnień, że polityka cesarza Franciszka Józefa ma być kontynuowana. Jesteśmy materialnie zawsze gotowi do rokowań z Ukraińcami, ale tylko na podstawie jedności kraju" ${ }^{56}$. Natomiast dużo miejsca aspiracjom narodów słowiańskich poświęcił pozostający poza obrębem Koła Ignacy Daszyński, wyrażając przy okazji niepokój z powodu uzależnienia się Austro-Węgier od Niemiec. Przywódca PPSD Galicji i Śląska stwierdzał na ten temat: „Austria dostała się w zależność od Niemiec (...) Dwie trzecie państwa tworzą nie Niemcy, którzy muszą w zależności od państwa niemieckiego widzieć nieszczęście narodowe, polityczne i gospodarcze. Nie można więc dziwić się, że w miarę zanikania samodzielności Austrii narody słowiańskie wykazały coraz większy niepokój, a z chwilą, kiedy Austria zaciągnęła się w rydwan Niemiec wzmogła się beznadziejność narodów słowiańskich i stworzy ona istotę sytuacji w parlamencie. Istnieje w Austrii naród, który zdradza odmienne interesy i uczucia. Są nim Niemcy, lecz nie reprezentują oni żadnej austriacko-politycznej myśli, lecz tylko myśl narodowo-niemiecką (...) Właśnie Słowianie stanowią jedyną siłę, która może Austrię ocalić przed wzrastającą przemocą Niemiec, podczas gdy jedna z podpór tronu i do patriotów państwowych zaliczają się tylko Niemcy, patrząc na Berlin i niemiecką kwaterę główną (...) W Austrii ściga się całe narody, występując przeciw Słowianom południowym, Czechom i Polakom, ponieważ nie chcą oni być poddanymi Niemiec"57.

Opozycja posłów polskich, czeskich i południowosłowiańskich doprowadziła 22 lipca 1918 r. do upadku rządu Seidlera. Jego miejsce zajął powołany dwa dni później gabinet kierowany przez konserwatywnego polityka niemiecko-austriackiego, Maxa Hussarka. Nowy prezydent ministrów podjął próbę osłabienia nasilających się tendencji odśrodkowych wśród narodów monarchii. O nominacji Hussarka zadecydowało w dużym stopniu stanowisko Koła Polskiego, ponieważ zobowiązał się on do niepodejmowania działań na rzecz podziału Galicji i opowiadał się za realizacją rozwiązania austro-polskiego. Czytamy w sprawozdaniu NKN: „Nominacja Hussarka jest dla Polaków korzystną. Przede wszystkim wie on, że tylko Polakom zawdzięcza swe stanowisko, toteż oświadczył natychmiastową gotowość wykonania długiej listy postulatów przedstawionych mu przez Tertila (niepodzielność Galicji, stosunek do Ukraińców, zasiłki na odbudowę kraju), jako klerykalny konserwatysta, tzw. Stara

55 „Nowa Reforma”, 4.07.1918, nr 282, s. 1.

${ }^{56}$ Stenographische Protokolle über die Sitzungen des Hauses der Abgeordneten össtereichischen Reichsrathes. XII Session, Sitzung 76, Bd IV, Wien 1919 (dalej cyt.: Stenographische Protokolle...), s. 3854 .

57 Tamże, s. 3982-3983. 
Austria, należy do ludzi dbających o niezależność Austrii od Berlina, jest zwolennikiem austro-polskiego rozwiązania"58. Identycznie oceniała tę nominację „Nowa Reforma”: „Z chwilą, gdy do steru rządu przyszedł niemiecki autonomista, szczery katolik, a nade wszystko zwolennik niezależności politycznej monarchii habsburskiej, jakim zapowiadał się dr. Hussarem, szanse porozumienia się między Polakami a umiarkowanymi i austriacko-dynastyczną politykę prowadzącymi Niemcami poszły niepomiernie"59.

Przychylny stosunek Koła Polskiego do gabinetu Hussarka sprawił, że politycy galicyjscy próbowali bezskutecznie przekonać posłów czeskich i południowosłowiańskich, aby zachowali absencję podczas głosowania nad budżetem. Przeciw budżetowi głosowali pozostający poza obrębem Koła przedstawiciele narodowych demokratów i socjalistów. Budżet został jednak uchwalony, ponieważ za jego przyjęciem oddała swoje głosy część posłów niemieckich ${ }^{60}$.

Późna wiosna i lato 1918 r. przyniosły nawiązanie kontaktów przez narodowych demokratów, socjalistów i ludowców z politykami słowiańskimi z Austro-Węgier. Przedstawiciele tych stronnictw wzięli bowiem udział w połowie maja w uroczystościach w Pradze z okazji pięćdziesięciolecia założenia Teatru Narodowego oraz w zorganizowanych w połowie sierpnia „dniach słowiańskich” w Lublanie. Deklarowali oni wówczas wolę współpracy narodów słowiańskich w Austro-Węgrzech w walce o realizację ich aspiracji niepodległościowych, a także po zakończeniu wojny. Obecny na uroczystościach w Lublanie przywódca narodowych demokratów Aleksander Skarbek w odpowiedzi na hasło niemieckiej Mitteleuropy, która wyrażała się w słowach „Od Hamburga do Bagdadu”, rzucił hasło „Od Triestu do Gdańska” ${ }^{61}$.

Na potrzebę współpracy narodów słowiańskich w monarchii habsburskiej zwracał również uwagę w Radzie Państwa poseł ludowy Włodzimierz Tetmajer: „To istniejące jeszcze państwo (Austro-Węgry - J. G.) nie może istnieć. Ono może jako mocarstwo dobrze funkcjonować dla całego wschodu Europy na zasadzie prawa do samostanowienia oraz uznania prawa do niezależności i wolności wszystkich narodów, zamieszkujących między Morzem Bałtyckim a Adriatyckim. Nadchodzi dla tych narodów wielkie zadanie zorganizowania między tymi morzami niezależnych państw" ${ }^{2}$.

Jeszcze bardziej wyraźnie wskazywał na zbieżność polskich i słowiańskich aspiracji narodowych publicysta organu galicyjskiego SDN, „Roku Polskiego”, Władysław Karniowski, pisał on na ten temat m.in.: „Za nawiązaniem przez Polaków jak najściślejszych węzłów z Czechosłowakami i Jugo-Słowianami przemawia wiele potężnych argumentów. Najpierw wspólność interesów politycznych wystąpiła zupełnie wyraźnie

58 Sprawozdanie z 30.07.1918, APKr., mkr. 100.268 (brak numeru karty).

59 „Nowa Reforma”, 24.07.1918, nr 316, s. 1.

${ }^{60} \mathrm{H}$. Rumpler, Max Hussarek. Nationalitäten und Nationalitätenpolitik in Österreich im Sommer des Jahres 1918, Graz-Köln 1965, s. 34-35.

${ }^{61}$ M. Paulová, dz. cyt., s. 455 i n.; M. Pułaski, Z dziejów genezy «Europy Wersalskiej». Współpraca Słowian zachodnich i południowych w ostatnim etapie I wojny światowej, Wrocław 1974, s. 118-119.

${ }^{62}$ Stenographische Protokolle..., XII Session, Sitzung 76, Bd III, Wien 1918, s. 2892. 
w ciągu tej wojny. Okazało się, że wtedy, gdy zyskiwała sprawa polska, zyskiwała i sprawa Czecho-Słowaków i Jugo-Słowian i na odwrót (...) Polityki polskiej w tej wojnie nie można izolować od innych analogicznych spraw, a to tym bardziej nie wolno poświęcać interesów innych narodów słowiańskich dla przelotnych zdobyczy w Austrii. Winno o tym wiedzieć wiedeńskie Koło Polskie"63. Identyczna była treść uchwały podjętej przez działaczy endeckich z Galicji Wschodniej na początku października 1918 r. w chwili rozpadu Austro-Węgier, w której podkreślano, że państwo polskie powinno być „w szczególny sposób związane z państwami zachodniej i południowej Słowiańszczyzny" ${ }^{64}$.

Natomiast w Kole Polskim zgodnie z jego proaustriackim stanowiskiem w dalszym ciągu nie dopuszczano możliwości realizacji aspiracji narodów słowiańskich w monarchii habsburskiej. Odzwierciedlała to opinia przedstawiona w końcu lipca 1918 r. przez „Nową Reformę”: „Bankructwo polityki Seidlerowskiej, która zamykała po prostu Czechom odwrót $\mathrm{z}$ ich dotychczasowych stanowisk powinno umożliwić budowę złotego mostu dla tego silnego, patriotycznego narodu ku państwu z powrotem. Te same możliwości otwierają się dla nowego rządu w stosunku do Słowian południowych" 65 .

W chwili zaś postępującego rozpadu Austro-Węgier na początku października stosunki między przyszłym państwem polskim a narodami słowiańskimi w monarchii były przedmiotem obrad Koła Polskiego, w którym uczestniczyli również socjaliści i narodowi demokraci. Daszyński przedstawił wówczas wniosek, aby Koło oświadczyło się, „za poparciem dążeń niepodległościowych innych narodów słowiańskich w Austrii". W podobnym tonie wypowiadał się A. Skarbek, domagając się uznania przez polityków galicyjskich prawa Czechów, Słowian południowych do utworzenia niepodległych państw ${ }^{66}$. Uchwalona deklaracja Koła nie zawierała jednak żadnej wzmianki na temat aspiracji innych narodów słowiańskich. Opowiedziano się w niej bowiem za utworzeniem w pełni niepodległego, zjednoczonego państwa polskiego. Należy dodać, że deklaracji tej nie podpisali przedstawiciele konserwatystów zachodniogalicyjskich ${ }^{67}$. Takie stanowisko wynikało $\mathrm{z}$ faktu, że do końca istnienia monarchii habsburskiej opowiadali się oni za jej utrzymaniem. Zakładali bowiem, że państwo polskie, otoczone od wschodu i zachodu przez potężnych sąsiadów, może zachować niepodległość tylko w związku z Austro-Węgrami. Dawał temu wyraz w końcu września "Czas”: „Państwo polskie, oparte w drodze umowy państwowej o monarchię habsburską, byłoby państwem jeszcze w wyższej mierze niepodległym, jak są nim dzisiaj Węgry, a pomoc innych narodów, razem z nim w związku pozostających, zabezpieczyłaby je przed losem każdego małego państwa buforowego, wtłoczonego między takie dwa

${ }^{63}$ W. Karniowski, Zachodni Słowianie a Polska, „Rok Polski”, Kraków 1918, nr 9, s. 505-507.

${ }^{64}$ A. Wątor, dz. cyt., s. 368.

65 „Nowa Reforma”, 30.07.1918, nr 326, s. 1.

66 „Naprzód”, 2.10.1918, nr 218, s. 1.

${ }^{67}$ „Naprzód”, 4.10.1918, nr 220, s. 1. Konserwatyści motywowali swoje stanowisko faktem, że prezes Koła T. Tertil nie zaprosił ich na konferencję. 
kamienie młyńskie, jakim byłby 70-milionowy naród niemiecki i 100-milionowy naród rosyjski. Problem stworzenia żywotnego i politycznie zabezpieczonego państwa przez kilkanaście milionów Polaków byłby w takim razie pomyślnie rozwiązany"68.

Współpraca między państwem polskim a państwami słowiańskimi w Europie środkowej mogła być jednak wyłącznie przedmiotem spekulacji teoretycznych. Przyczyniły się do tego w głównej mierze rozbieżności polsko-czeskie na tle zasięgu terytorialnego państwa polskiego i granicy na Śląsku Cieszyńskim. Przywódcy czeskiej akcji niepodległościowej sprzeciwili się bowiem przyłączeniu do Polski obszarów na wschód od Bugu, w tym i Galicji Wschodniej, oraz, powołując się na argumenty historyczne, stali na gruncie przyłączenia większej części Śląska Cieszyńskiego do państwa czechosłowackiego. Kontrowersje te rzutowały negatywnie na stosunki między Komitetem Narodowym Polskim a Czechosłowacką Radą Narodową w końcowej fazie wojny ${ }^{69}$.

Galicia politicians to the internal situation in Austria-Hungary at the end of World War I (1917-1918)

The Austro-Polish orientation adopted by almost all Polish parties in Galicia evoked their interest in the internal situation in the western part of the Habsburg Monarchy, Przedlitawia. It caused a considerable influence on the international position of the Monarchy, especially on its relationship with the German Empire, which represented a great importance of the position for the authorities in Vienna to the Polish case.

The increase of Galician politicians' interest in the internal situation of Przedlitawia occurred in 1917 when the Polish case became an international issue, and the State Council convention brought an escalation of the national aspirations of Czechs and southern Slavs, which evolved towards independence. Polish envoys dissociated themselves from demands made by the representatives of these nations, because the realization of the demands could only occur in the case of a change of a constitutional and political structure of Austria-Hungary. Particularly, this applied to the postulate of the connection of Slovakia to the Czech state. Such position of the Polish Circle enabled the cooperation with the Slav envoys. Hopes for the realization of the Austro-Polish solution and fears against the support of the Vienna government and the German parties for the Ukrainian efforts of Galicia contributed to such position. All this meant that even after the Treaty of Brest-Litovsk Galician envoys with the exception of the National Democrats and the Socialists did not join the opposition.

This was accompanied by a negative attitude towards the demands of German political parties. Their efforts to strengthen the alliance between Austria-Hungary and Germany were subject to particular criticism. The Polish Circle relations with the German parties had a negative effect on their reluctant attitude to the Austro-Polish solution.

However, the position of the majority of Galicia envoys towards the aspirations of the Slavic nations did not change until the end of the war. For the cooperation with these nations, the National Democrats, Socialists and Populists were in favor of in the final phase of the war. But despite the declarations submitted by representatives of these parties any decision on this cooperation was not taken during the war.

68 „Czas”, 24.09.1918, nr 422, s. 1.

69 M. Pułaski, dz. cyt., s. 69 i n.; K. Lewandowski, Sprawa ukraińska w polityce zagranicznej Czechosłowacji w latach 1918-1932, Wrocław 1974, s. 23-25. 
Галицийские политики по отношению к внутреннему положению в Австро-Венгрии в конце Первой мировой войны (1917-1918)

Принятая всеми польскими партиями в Галиции австро-польская политическая ориентация привела к тому, что возросла их заинтересованность внутренней ситуацией в западной части Габсбургской монархии, Цислейтании. Ситуация эта оказывала влияние на международное положение монархии, особенно на её отношения с Германской империей, что представляло огромное значение для позиции властей Австро-Венгрии по отношению к польскому вопросу.

Рост заинтересованности галицийских политиков внутренним положением Цислейтании наступил в 1917 г., когда польский вопрос стал вопросом международным, а образование Государственного Совета привело к росту стремлений Чехии и южных славян к независимости. Польские депутаты не признавали выдвигаемые представителями этих наций требований, потому что их реализация могла наступить только в случае изменения политического устройства Австро-Венгрии. Особенно это относилось к требованию о присоединении к чешскому государству Словакии. Такое положение Польского Кружка сделало невозможным его сотрудничество со словянскими депутатами. Причиной тому послужили надежды на решение австро-польского вопроса и боязнь поддержки правительством в Вене и немецкими партиями украинцев в вопросе по разделу Галиции. Все это привело к тому, что даже после Брестского договора галицийские послы за исключением национальных демократов и социалистов не перешли в оппозицию.

Сопутствовало этому негативное отношение к предложениям, выдвигаемых немецкими партиями. Особенной критике подвергались их стремления к более тесному союзу Австро-Венгрии с Германией. На отношения Польского кружка с немецкими партиями негативно влияло также их неохотное отношение к решению австро-польского вопроса.

Зато позиция большинства галицийских депутатов по отношению к стремлениям славянских народов не изменилась до окончания войны. За сотрудничество с этими народами в конечной фазе войны были национал-демократы, социалисты и народовцы. Но, несмотря на предложения этих партий, до окончания войны не было принято никакого решения по вопросу данного сотрудничества. 